\title{
Corticotropin-releasing Hormone Excites Adrenocorticotropin-secreting Human Pituitary Adenoma Cells by Activating a Nonselective Cation Current
}

\author{
Koji Takano, ${ }^{\star}$ Junko Yasufuku-Takano, ${ }^{\star}$ Akira Teramoto, ${ }^{\ddagger}$ and Toshiro Fujita* \\ *Fourth Department of Internal Medicine, University of Tokyo School of Medicine, 3-28-6 Mejirodai, Bunkyo-ku, Tokyo 112, Japan; \\ and ${ }^{\ddagger}$ Department of Neurosurgery, Nippon Medical School, 1-1-5 Sendagi, Bunkyo-ku, Tokyo 113, Japan
}

\begin{abstract}
The mechanisms of corticotropin-releasing hormone (CRH)induced excitation of ACTH-secreting adenoma cells were investigated using the perforated whole-cell clamp technique and intracellular $\mathrm{Ca}^{2+}$ concentration $\left(\left[\mathrm{Ca}^{2+}\right]_{\mathrm{i}}\right)$ measurement. CRH depolarized ACTH-secreting adenoma cells by activating a nonselective cation current that showed slight inward rectification. This channel did not seem to be a member of the $\mathrm{Ca}^{2+}$-activated cation currents because it was activated even when the $\left[\mathrm{Ca}^{2+}\right]_{i}$ was chelated below $50 \mathrm{nM}$. The activation of the current was induced by protein kinase A-mediated pathways. $\mathrm{By}\left[\mathrm{Ca}^{2+}\right]_{i}$ measurement, $\mathrm{CRH}$ increased $\left[\mathrm{Ca}^{2+}\right]_{i}$ of these cells dependently on voltage-gated $\mathrm{Ca}^{2+}$ current. This $\mathrm{CRH}$-induced $\left[\mathrm{Ca}^{2+}\right]_{\mathrm{i}}$ increase was abolished in $\mathrm{Na}^{+}$-free extracellular solution, but was not abolished by the addition of $5 \mu \mathrm{M}$ tetrodotoxin to the extracellular solution. CRH-induced ACTH secretion from the cultured adenoma cells was also abolished in $\mathrm{Na}^{+}$-free extracellular solution, but not in tetrodotoxin-containing extracellular solution. These data indicate that a $\mathrm{Na}^{+}$current (maybe the nonselective cation current) other than voltagegated $\mathrm{Na}^{+}$current plays an important role in $\mathrm{CRH}$-induced $\left[\mathrm{Ca}^{2+}\right] \mathrm{i}$ increase and ACTH secretion. $\mathrm{CRH}$ also activated a nonselective cation current in nonadenoma human corticotrophs, suggesting that the activation of a nonselective cation current is a physiological mechanism of CRHinduced excitation in human corticotrophs. (J. Clin. Invest. 1996. 98:2033-2041.) Key words: corticotropin-releasing hormone - corticotroph - nonselective cation current - protein kinase $\mathrm{A} \cdot$ adrenocorticotropin secretion
\end{abstract}

\section{Introduction}

Corticotropin-releasing hormone $(\mathrm{CRH})^{1}$ is one of the major regulatory hormones of the neuroendocrine response to stress

Address correspondence to Koji Takano, Fourth Department of Internal Medicine, University of Tokyo School of Medicine, 3-28-6 Mejirodai, Bunkyo-ku, Tokyo 112, Japan. Phone: 81-3-3943-1151; FAX: 81-3-3943-3102.

Received for publication 27 June 1996 and accepted in revised form 29 August 1996.

1. Abbreviations used in this paper: $\left[\mathrm{Ca}^{2+}\right]_{\mathrm{i}}, \mathrm{Ca}^{2+}$ concentration; $\mathrm{CRH}$, corticotropin-releasing hormone; PKA (or PKC), protein kinase A (or C); PKI, a PKA inhibitor peptide; TMA, tetramethylammonium; TTX, tetrodotoxin.

J. Clin. Invest.

(C) The American Society for Clinical Investigation, Inc.

0021-9738/96/11/2033/09 \$2.00

Volume 98, Number 9, November 1996, 2033-2041
$(1,2)$. Secreted from the hypothalamic CRH-neurons into a pituitary portal system in response to stress, CRH stimulates ACTH secretion from corticotrophs in the anterior pituitary (2). The mechanism of CRH-induced ACTH secretion has been investigated using rat corticotrophs and AtT-20 cells, an ACTH-secreting mouse pituitary cell line, and ACTH-secreting human pituitary adenoma cells. CRH stimulates ACTH secretion through the activation of adenylyl cyclase $(3,4)$ and through the increase in intracellular $\mathrm{Ca}^{2+}$ concentration $\left(\left[\mathrm{Ca}^{2+}\right]_{\mathrm{i}}\right)$ $(5,6)$. CRH-induced $\left[\mathrm{Ca}^{2+}\right]_{\mathrm{i}}$ increase is due to the $\mathrm{Ca}^{2+}$ influx through voltage-gated $\mathrm{Ca}^{2+}$ channels, which is stimulated by CRH through protein kinase A (PKA)-mediated pathways $(5,7)$. In addition to $\mathrm{CRH}$-induced activation of voltage-gated $\mathrm{Ca}^{2+}$ channels, $\mathrm{CRH}$ depolarizes ACTH-secreting cells and increases action potential frequency that is accompanied by $\left[\mathrm{Ca}^{2+}\right]_{i}$ transients (7). These suggest that the increased frequency of action potential augments $\mathrm{Ca}^{2+}$ influx through the voltage-gated $\mathrm{Ca}^{2+}$ channels that are open during action potentials. To understand the significance of the $\mathrm{CRH}$-induced excitation in ACTH secretion, it is necessary to investigate the mechanism of $\mathrm{CRH}$-induced excitation and its relation to $\left[\mathrm{Ca}^{2+}\right]_{i}$ increase and ACTH secretion. We investigated these ionic mechanisms by electrophysiological experiments using perforated whole-cell clamp on human ACTH-secreting adenoma cells and nonadenoma human corticotrophs. We found that CRH excited ACTH-secreting adenoma cells by activating a nonselective cation current through the PKA-mediated pathway. This CRH-induced activation of a cation current played an important role in $\mathrm{CRH}$-induced $\left[\mathrm{Ca}^{2+}\right]_{\mathrm{i}}$ increase and ACTH secretion. This is the first report that showed CRHinduced activation of a nonselective cation current in vertebrate cells, including human corticotroph.

\section{Methods}

Drugs. CRH, PKC(19-36), a protein kinase C (PKC) inhibitor peptide, and PKI(5-24), a PKA inhibitor peptide, were purchased from Peninsula Laboratories Inc. (Belmont, CA). 8-bromoadenosine 3',5' cyclic monophosphate ( $8 \mathrm{Br}$-cAMP), forskolin, and nystatin were purchased from Sigma Chemical Co. (St. Louis, MO). $N$-[2-( $p$-bromocinnamylamino)ethyl]-5-isoquinoleinsulfonamide (H89) was purchased from Seikagaku-kogyo Co., Ltd. (Tokyo, Japan), and dispase from Godo Shusei Co., Ltd. (Tokyo, Japan). Fura 2/AM was purchased from Molecular Probes, Inc. (Eugene, OR).

Cell preparation. ACTH-secreting pituitary adenomas were obtained with informed consent from three patients operated for ACTH-secreting pituitary adenoma by transsphenoidal surgery (patients 1-3). The use of surgically removed human pituitary tissues obtained during surgery as experimental materials is permitted by the Investigation Committee of Hypothalamo-Pituitary Diseases, The Ministry of Health and Welfare of Japan, and The Ethical Committee of University of Tokyo School of Medicine (Tokyo, Japan). Preoperative serum ACTH levels of these patients were $61 \mathrm{pg} / \mathrm{ml}$ in patient 1 , $53 \mathrm{pg} / \mathrm{ml}$ in patient 2 , and $90 \mathrm{pg} / \mathrm{ml}$ in patient 3 . All three patients re- 
sponded to $100 \mu \mathrm{g}$ intravenous $\mathrm{CRH}$ administration, peak ACTH value was $132 \mathrm{pg} / \mathrm{ml}$ in patient $1,155 \mathrm{pg} / \mathrm{ml}$ in patient 2 , and $210 \mathrm{pg} / \mathrm{ml}$ in patient 3 . The excised adenoma tissues were minced into small pieces $(<1 \mathrm{~mm})$ and were digested with $1,000 \mathrm{U} / \mathrm{ml}$ dispase. For investigating the hormonal release, cells were seeded on 24-well dishes at a density of $10^{5}$ cells/well. For $\left[\mathrm{Ca}^{2+}\right]_{\mathrm{i}}$ measurements, cells were seeded on $22-\mathrm{mm}$ round cover glasses and placed in $35-\mathrm{mm}$ culture dishes. For electrophysiological experiments they were seeded on 35-mm culture dishes. Cells were cultured in DMEM containing $10 \%$ heat-inactivated FCS, and kept in humidified air containing $5 \%$ $\mathrm{CO}_{2}$ at $37^{\circ} \mathrm{C}$. All the experiments were carried out using cells cultured for 1 to $2 \mathrm{wk}$.

Nonadenoma human anterior pituitary cells were obtained by transsphenoidal surgery from another patient suffering from Cushing's disease. As part of the surgical procedure, it is sometimes inevitable to remove some small pieces of normal tissue from the anterior pituitary to reveal the adenoma tissue. The patient had been informed about this possibility in advance and he gave his consent that such normal tissue could be used for this experiment in the case that it had to be removed when looking for the adenoma. The normal pituitary tissue was digested and seeded on $35-\mathrm{mm}$ tissue culture dishes by the same method as stated above. Cells were cultured in the same manner as described for the ACTH-secreting adenoma cells. After electrophysiological experiments, cells that responded to CRH application were stained for human $\mathrm{ACTH}$ and were confirmed to be ACTH-secreting cells (see Cell identification, below).

Electrophysiology. The perforated whole-cell clamp technique was used (8). The standard patch electrode solution contained the following (in $\mathrm{mM}$ ): $95 \mathrm{~K}$ aspartate, $47.5 \mathrm{KCl}, 1 \mathrm{MgCl}_{2}, 0.1$ EGTA (tetramethylammonium [TMA] salt, $\mathrm{pH} 7.2$ ), and 10 Hepes. The standard external solution was as follows (in $\mathrm{mM}$ ): $128 \mathrm{NaCl}, \mathrm{pH} 7.4,5$ $\mathrm{KCl}, 1 \mathrm{MgCl}_{2}, 2.5 \mathrm{CaCl}_{2}$, and $10 \mathrm{Hepes}$. The $\mathrm{Na}^{+}$-free solution was made by replacing $\mathrm{Na}^{+}$of the standard solution with isoosmotic $\mathrm{TMA}^{+}$or isoosmotic choline ${ }^{+}$. Other cation-substituted solutions except for $\mathrm{Na}^{+}$-free solution were made by replacing $\mathrm{Na}^{+}$and $\mathrm{K}^{+}$in the standard solution with isoosmotic cation $\left(\mathrm{Li}^{+}\right.$or $\left.\mathrm{NH}_{4}^{+}\right)$. Other changes in the composition of the extracellular and internal solutions are noted. During the experiments, the extracellular solution was continuously perfused by a peristaltic pump. Agonists were applied by changing the perfusing solution. It took $\sim 2 \mathrm{~min}$ to change the bath solution with this peristaltic pump system. The liquid junction potentials between the standard extracellular solution and other solutions used (internal and external) were measured using a $3 \mathrm{M} \mathrm{KCl}$ electrode as a reference, and all the data were corrected for the liquid junction potential ( -8 to $2 \mathrm{mV}$ ). An amplifier (EPC-7; List Biological Labs, Inc., Campbell, CA) was used for recording the membrane current and potential. All experiments were performed at room temperature $\left(22-25^{\circ} \mathrm{C}\right)$. Glass capillaries of $1.5 \mathrm{~mm}$ diameter with a filament were used to make patch electrodes. The resistance of the patch electrodes were between 5 and $8 \mathrm{M} \Omega$. Details of the perforated whole-cell clamp technique have been reported elsewhere (9). Current clamp recordings were started after the series resistance fell below $50 \mathrm{M} \Omega$. Voltage clamp recordings were made after the series resistance fell below $20 \mathrm{M} \Omega$. Since the amplitude of the current was $<150 \mathrm{pA}$, the errors caused by series resistance were ignored.

Microinjection of peptides. PKI(5-24) and PKC(19-36) were injected into the cell by microinjection. The details of the method for microinjection have already been reported (10). The peptides were dissolved in $150 \mathrm{mM} \mathrm{KCl}$ at the concentration of $0.1 \mathrm{mM}$. The peptide solution was microinjected through microcapillaries with a tip resistance of $20 \mathrm{M} \Omega$ by pressure injection $(110 \mathrm{hPa}, 0.1 \mathrm{~s})$. At the time of injection, a slight swelling of the cell was observed. The volume of the injected solution was estimated approximately by the decrease of the solution after multiple injections. The injected solution was $\sim 10-30$ fl per cell, which was $\sim 1 / 100$ of the cell volume (500-1,500 fl). Microinjection was performed $20 \mathrm{~min}$ before patch clamping. The cells with input resistance of more than $1 \mathrm{G} \Omega$ after the microinjection were used for the experiments.
$\left[\mathrm{Ca}^{2+}\right]_{i}$ measurement. Cells were loaded with fura 2 by incubating with $2 \mu \mathrm{M}$ fura 2/AM in Hanks' balanced salt solution containing $0.1 \%$ bovine serum albumin for $40 \mathrm{~min}$ at room temperature. $\mathrm{Ca}^{2+}$ measurements were performed on a Nikon Diaphot microscope (Nikon, Tokyo, Japan). Each cell was excited at 340 and $380 \mathrm{~nm}$ alternately at a frequency of $100 \mathrm{~Hz}$ with CAM220 (Nihonbunko, Tokyo, Japan). A band filter was used to monitor the fluorescent emission at $510 \mathrm{~nm}$. The cytosolic free $\mathrm{Ca}^{2+}$ concentration was determined from the equation $\left[\mathrm{Ca}^{2+}\right]_{\mathrm{i}}=\mathrm{K}\left(\mathrm{R}-\mathrm{R}_{\min }\right) /\left(\mathrm{R}_{\max }-\mathrm{R}\right)$ (11). In this equation, $\mathrm{K}$ represents $\mathrm{Kd}\left(\mathrm{F}_{\min } / \mathrm{F}_{\text {max }}\right)$, where $\mathrm{Kd}$ is the dissociation constant of fura $2\left(130 \mathrm{nM}\right.$ at $\left.25^{\circ} \mathrm{C}\right)$, and $\mathrm{F}_{\max } / \mathrm{F}_{\min }$ is the ratio of $\mathrm{Ca}^{2+}$-free and -bound fura 2 fluorescence at $380 \mathrm{nM} . \mathrm{R}_{\min }$ is the $340 / 380$ fluorescence ratio of $\mathrm{Ca}^{2+}$-free fura 2 , and $\mathrm{R}_{\max }$ is the 340/380 ratio of $\mathrm{Ca}^{2+}$ bound fura 2 . Calibration was performed on every cell by permeabilizing the cell to $\mathrm{Ca}^{2+}$ with $2 \mu \mathrm{M}$ digitonin. Cells were first permeabilized in $\mathrm{Ca}^{2+}$-free saline $(5 \mathrm{mM}$ EGTA, $150 \mathrm{mM} \mathrm{KCl}$, and $10 \mathrm{mM}$ Hepes, $\mathrm{pH}$ 7.2), for determination of $\mathrm{R}_{\min }$ and $\mathrm{F}_{\min }$, and then in high $\mathrm{Ca}^{2+}$ saline $\left(2.5 \mathrm{mM} \mathrm{CaCl}_{2}, 150 \mathrm{mM} \mathrm{KCl}\right.$, and $10 \mathrm{mM}$ Hepes, $\left.\mathrm{pH} 7.4\right)$ for determination of $\mathrm{R}_{\max }$ and $\mathrm{F}_{\max }$. The $\left[\mathrm{Ca}^{2+}\right]_{\mathrm{i}}$ traces shown in the figures were filtered with a bandwidth of $1 \mathrm{~Hz}$ to reduce the noise. Agonists were applied by changing the bath solution with a peristaltic pump. In the $\left[\mathrm{Ca}^{2+}\right]_{\mathrm{i}}$ measurement experiment, it took $\sim 30 \mathrm{~s}$ to change the bath solution in this peristaltic pump system.

Hormonal release study. Adenoma cells cultured in 24-well dishes were washed twice with serum-free DMEM containing $0.1 \%$ BSA. They were incubated with the same medium containing $100 \mathrm{nM}$ $\mathrm{CRH}$ for $2 \mathrm{~h}$ with or without $2 \mu \mathrm{M}$ nitrendipine or $10 \mu \mathrm{M}$ forskolin. Some cells were pretreated with $5 \mu \mathrm{M}$ H89, a PKA inhibitor, for $1 \mathrm{~h}$. After H89 pretreatment, cells were treated with or without $100 \mathrm{nM}$ $\mathrm{CRH}$ for $2 \mathrm{~h}$. For the experiments using $\mathrm{Na}^{+}$-free extracellular solution, cells were incubated in $\mathrm{Na}^{+}$-free extracellular solution (see above) containing $100 \mathrm{mg} / \mathrm{dl}$ glucose with or without $100 \mathrm{nM} \mathrm{CRH}$ for $2 \mathrm{~h}$. After the incubation with various agents, the solution was collected and stored at $-20^{\circ} \mathrm{C}$ until the hormonal assay. ACTH was assayed using a radioimmunometric assay kit (Daiichi Radioisotope Laboratories, Tokyo, Japan).

Cell identification. At an early stage of the experiments, the cells were stained against human ACTH immunocytochemically to identify ACTH-secreting adenoma cells. Cells $(n=7)$ that showed membrane hyperpolarizations in response to $\mathrm{CRH}$ application (see below) were fixed by $2 \%$ formaldehyde in phosphate buffer and stained for human ACTH by using a human ACTH immunostaining kit (DAKO SA, Glostrup, Denmark). All these cells stained positive for ACTH. In the subsequent experiments, data were obtained from cells that satisfied the criteria for pituitary adenoma cells obtained from our experience, which is round-shaped cells with a diameter of 10-20 $\mu \mathrm{m}$ that have a smooth glittering surface under a scanning light microscope. These characteristics were apparently different from the characteristics of the spindle-shaped fibroblast-like cells that grew in the adenoma cell culture.

\section{Results}

Membrane depolarization by $C R H$. Fig. $1 A$ shows a potential record from a human ACTH-secreting adenoma cell under current clamp in the standard extracellular solution. The pipette solution was the standard internal solution. The resting membrane potential of this cell was $\sim-52 \mathrm{mV}$ and this cell exhibited spontaneous action potentials. Spontaneous action potentials were observed in $84 \%$ of the examined cells $(n=$ 50). Application of $1 \mathrm{nM} \mathrm{CRH}$ induced depolarization to the level of $-40 \mathrm{mV}$ and increased action potential frequency. When CRH was washed out from the bath solution, the membrane potential reversed to the basal level. CRH (10 nM)induced depolarization was observed in 10 out of 10 cells from adenoma 1,11 out of 12 cells from adenoma 2 , and 8 out of 8 


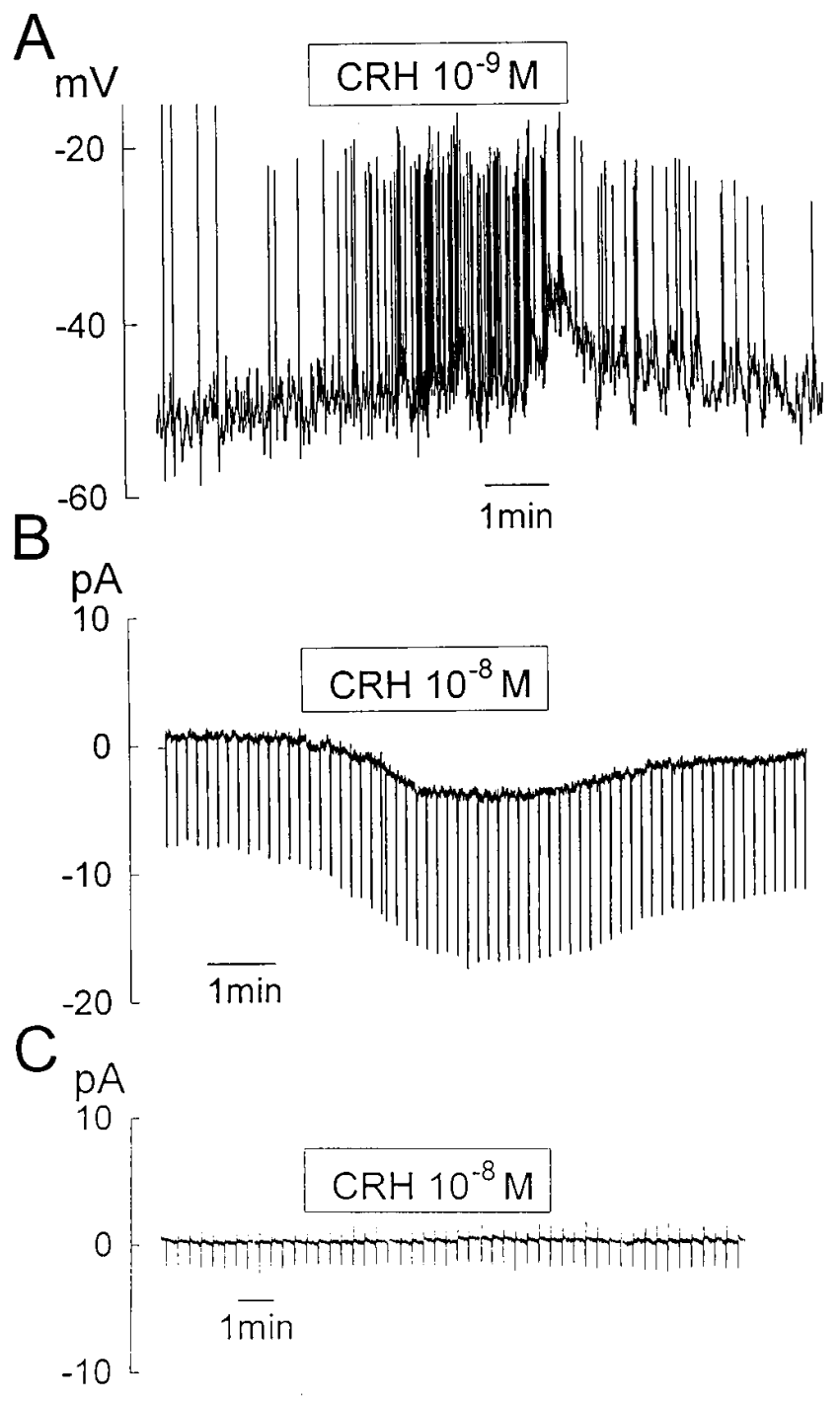

Figure 1. (A) Membrane depolarization caused by CRH in an $\mathrm{ACTH}$-secreting pituitary adenoma cell. The cell exhibits spontaneous action potentials and the resting membrane potential was -52 $\mathrm{mV}$. Application of $1 \mathrm{nM} \mathrm{CRH}$ depolarized the membrane and increased the action potential frequency. $(B)$ The current record from another cell under voltage clamp at holding potential of $-48 \mathrm{mV}$. Application of CRH $(10 \mathrm{nM})$ induced inward current accompanied by membrane conductance increase. The membrane conductance was measured by applying a hyperpolarizing pulse of $-60 \mathrm{mV}$ every $10 \mathrm{~s}$. (C) The current record of another cell under voltage clamp in $\mathrm{Na}^{+}-$ free $\left(\mathrm{TMA}^{+}\right.$-substituted) extracellular solution. The holding potential was $-48 \mathrm{mV}$. Membrane conductance was monitored by applying hyperpolarizing pulse of $-60 \mathrm{mV}$ every $20 \mathrm{~s}$. Application of CRH (10 $\mathrm{nM}$ ) did not induce an inward current.

cells from adenoma 3 . The mean value of depolarization induced by $10 \mathrm{nM} \mathrm{CRH}$ was $9.6 \pm 4.5 \mathrm{mV}$ (mean $\pm \mathrm{SD}, n=29$ ).

To examine the ionic mechanism of this $\mathrm{CRH}$-induced depolarization, whole cell currents were recorded under voltage clamp. Fig. $1 B$ shows the membrane current of another adenoma cell recorded under voltage clamp at a holding potential of $-48 \mathrm{mV}$. The membrane conductance was monitored by applying a $60-\mathrm{mV}$ hyperpolarizing pulse once every $10 \mathrm{~s}$. Application of $10 \mathrm{nM} \mathrm{CRH} \mathrm{evoked} \mathrm{an} \mathrm{inward} \mathrm{shift} \mathrm{of} \mathrm{the} \mathrm{holding}$ current accompanied by an increase in membrane conductance. This inward current was reversible when CRH was washed out from the bath solution.

These results indicate that $\mathrm{CRH}$-induced inward current is responsible for the $\mathrm{CRH}$-induced depolarization. Therefore we investigated the extracellular $\mathrm{Na}^{+-}$dependency of the CRH-induced inward current because $\mathrm{Na}^{+}$was the major cation in the extracellular solution. Fig. $1 C$ shows a current record of another adenoma cell in $\mathrm{Na}^{+}$-free $\left(\mathrm{TMA}^{+}\right.$-replaced) extracellular solution under voltage clamp. The membrane conductance was monitored by the method in Fig. 1 B. Application of $\mathrm{CRH}$ did not induce a noticeable current. This indicates that the CRH-induced inward current was extracellular $\mathrm{Na}^{+}$-dependent. $\mathrm{Na}^{+}$-free extracellular solution abolished $\mathrm{CRH}$-induced current in 11 out of 11 cells examined. This inward current under voltage clamp seems to correspond to the depolarization observed under current clamp because $\mathrm{CRH}$ induced depolarization was also abolished in $\mathrm{Na}^{+}$-depleted extracellular solution (data not shown).

Characteristics of the CRH-induced current. Fig. $2 \mathrm{~A}$, left and center, shows membrane currents under voltage clamp obtained before (control) and during $(\mathrm{CRH})$ the application of $10 \mathrm{nM} \mathrm{CRH}$, respectively. We used the standard extracellular solution and the holding potential was $-48 \mathrm{mV}$. The control current was subtracted from the current recorded during the $\mathrm{CRH}$ application to obtain $\mathrm{CRH}$-induced current (Fig. $2 A$, right). The I-V relation of $\mathrm{CRH}$-induced current in Fig. $2 A$, right is plotted against the membrane potential in Fig. $2 B,(\bigcirc)$, where the data from two other cells are included ( $\triangle$ and $\triangle$ ). The CRH-activated current showed slight inward rectification. Because the I-V curve was nearly linear between -48 and -78 $\mathrm{mV}$, the reversal potential of $\mathrm{CRH}$-induced current was estimated by extrapolating the I-V curve in this segment, which fell between -20 and $0 \mathrm{mV}$. This reversal potential was between the equilibrium potential of $\mathrm{Na}^{+}$and $\mathrm{K}^{+}$, which suggests that the $\mathrm{CRH}$-induced current is a nonselective cation current. The slope conductance between -48 and $-78 \mathrm{mV}$ of the $\mathrm{CRH}$ (10 $\mathrm{nM}$ )-induced current was $97 \pm 42 \mathrm{pS}$ (mean $\pm \mathrm{SD}, n=6)$ in adenoma $1,185 \pm 73 \mathrm{pS}$ in adenoma 2 , and $238 \pm 37 \mathrm{pS}$ in adenoma 3. Fig. $2 C$ shows the concentration dependency of the $\mathrm{CRH}$-induced conductance in adenoma 3. Maximum response was obtained at $>10 \mathrm{nM}$. Because the I-V relation showed little voltage dependency, a ramp test potential was used for further experiments.

Fig. $3 A$ shows the I-V relationship of the membrane current obtained by a ramp test potential over -120 to $-50 \mathrm{mV}$ in $800 \mathrm{~ms}$ from the holding potential of $-48 \mathrm{mV}$. When the I-V relations of the cell before and during $\mathrm{CRH}$ application were extrapolated, the extrapolating lines crossed between -20 and $0 \mathrm{mV}$. These indicate that the reversal potential measured approximately by ramp test protocol was close to the reversal potential estimated by pulse step protocol. The reversal potential of the CRH-induced current estimated by ramp pulse was $-10.5 \pm 7.9 \mathrm{mV}(n=6)$.

The ion selectivity of the channel responsible for the CRHinduced inward current was investigated. In these experiments, the extracellular $\mathrm{Na}^{+}$was replaced with other cations $\left(\mathrm{Li}^{+}\right.$, $\mathrm{NH}_{4}{ }^{+}$, or TMA ${ }^{+}$). Fig. 3, $B-D$ shows the effect of $10 \mathrm{nM} \mathrm{CRH}$ on the membrane current under voltage clamp in $\mathrm{Li}^{+}-, \mathrm{NH}_{4}{ }^{+}$, and $\mathrm{TMA}^{+}$-extracellular solution. The holding potential was $-48 \mathrm{mV}$. $\mathrm{CRH}$ induced a cation current in $\mathrm{Li}^{+}$- and $\mathrm{NH}_{4}{ }^{+}-$ extracellular solution. However in $\mathrm{TMA}^{+}$-extracellular solu- 


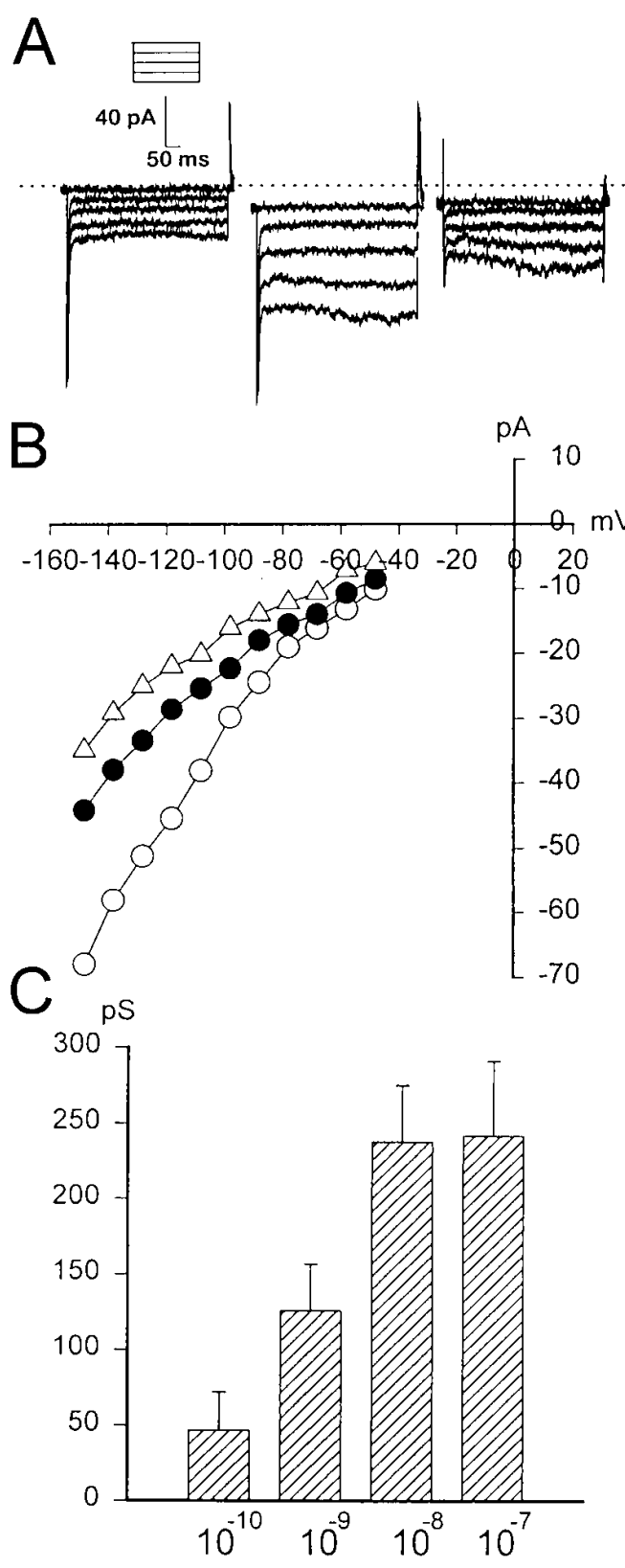

Figure 2. CRH-induced cation conductance. (A) Membrane currents under voltage clamp evoked by step pulse potentials before (left) and after (center) the application of $10 \mathrm{nM} \mathrm{CRH}$. We used the standard extracellular solution and the holding potential was $-48 \mathrm{mV}$. The test pulses were to $-48,-68,-88,-108$, and $-128 \mathrm{mV}$. The control current (left) was subtracted from that recorded during the CRH application (center) to obtain the CRH-induced current (right). The broken line is zero current level. $(B) \mathrm{I}-\mathrm{V}$ relation of $\mathrm{CRH}$-induced current $(O)$ in $(A)$, where I-V curves from two other cells are included $(-$ and $\triangle$ ). $(C)$ Dose dependency of CRH-induced conductance. $\mathrm{CRH}$-induced conductance was estimated by dividing the current difference of the $\mathrm{CRH}$-induced current at -48 and $-78 \mathrm{mV}$ by the potential difference $(30 \mathrm{mV})$.

tion, $\mathrm{CRH}$ did not activate a current. These indicate that the CRH-stimulated channel is permeable to $\mathrm{Li}^{+}$and $\mathrm{NH}_{4}{ }^{+}$, but not to $\mathrm{TMA}^{+}$. In addition to $\mathrm{TMA}^{+}$, choline ${ }^{+}$was used as an indifferent monovalent cation to substitute $\mathrm{Na}^{+}$in the extracellular solution. $\mathrm{CRH}$ did not activate a current in choline ${ }^{+}-$
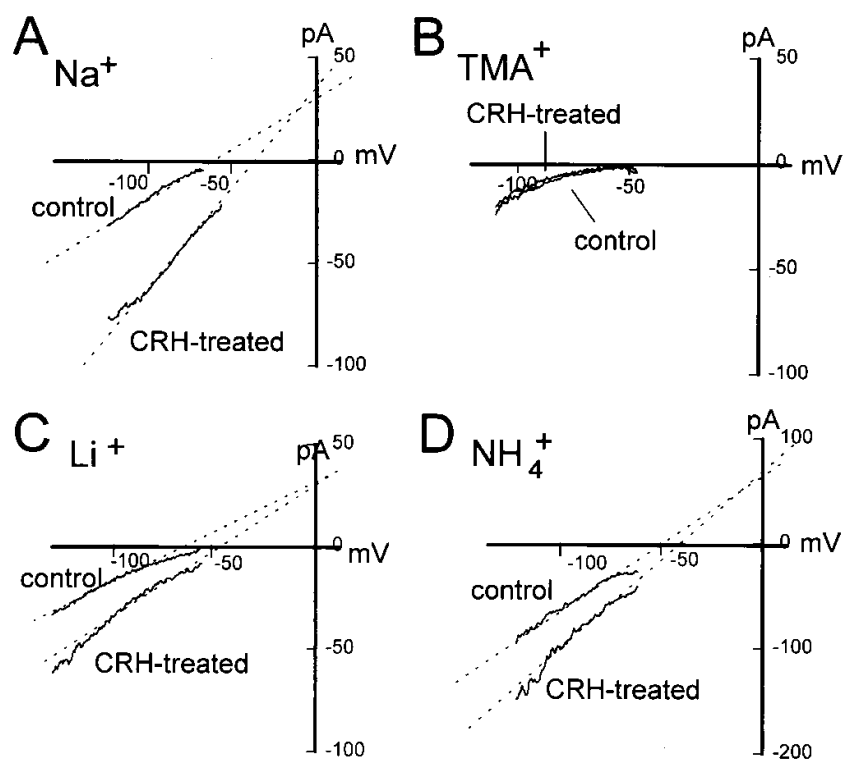

Figure 3. Ion selectivity of CRH-induced current. I-V relationships were obtained before and during application of $10 \mathrm{nM} \mathrm{CRH}$ using the ramp pulse protocol. Holding potential was $-48 \mathrm{mV}$, and dwell time of the ramp pulse from -150 to $20 \mathrm{mV}$ was $1 \mathrm{~s}$. Part of the current traces are shown. Standard extracellular solution was the extracellular solution in $A$, isoosmotic $\mathrm{TMA}^{+}$solution in $B, \mathrm{Li}^{+}$solution in $C$, and $\mathrm{NH}_{4}{ }^{+}$solution in $D$. Broken lines were drawn by eye. Control indicates current record before the application of $\mathrm{CRH}, \mathrm{CRH}$-treated indicates current record after the application of CRH.

extracellular solution either (data not shown). Similar results were obtained in more than three other cells in each cationexchanged extracellular solution.

To investigate the permeability of the $\mathrm{CRH}$-induced current for $\mathrm{Cl}^{-}$, the extracellular $\mathrm{Cl}^{-}$was reduced to $15 \mathrm{mM}$ by substituting $\mathrm{NaCl}$ with isoosmotic sodium methanesulfonate. Application of CRH induced a cation current in the low $\mathrm{Cl}^{-}$ solution (data not shown). The reversal potential of the CRHinduced current was $-8.3 \pm 7.8(n=5)$ and was close to that of the CRH-induced current obtained in the standard extracellular solution containing $140 \mathrm{mM} \mathrm{Cl}^{-}$. These indicate that the channel for the CRH-induced current is not permeable to $\mathrm{Cl}^{-}$.

To estimate the permeability ratio for $\mathrm{Na}^{+}$and $\mathrm{K}^{+}$of the $\mathrm{CRH}$-induced conductance, the reversal potential of the $\mathrm{CRH}$ (10 nM)-induced current was measured using a solution containing only $\mathrm{Na}^{+}$as a cation for extracellular solution and a solution containing only $\mathrm{K}^{+}$as a cation for intracellular solution. The reversal potential was $-8.8 \pm 6.8 \mathrm{mV}(n=5)$. If we hypothesize that $\mathrm{Na}^{+}$and $\mathrm{K}^{+}$flow are independent, the permeability ratio of $\mathrm{CRH}$-induced current to $\mathrm{K}^{+}$and $\mathrm{Na}^{+}$can be calculated by the Goldmann-Hodgkin-Katz equation $(12,13)$ : $\mathrm{E}_{\text {rev }}=\left(\mathrm{RT} / \mathrm{F} \bullet 1 \mathrm{n}\left\{\left(\mathrm{P}_{\mathrm{K}}[\mathrm{K}]_{\mathrm{o}}+\mathrm{P}_{\mathrm{Na}}[\mathrm{Na}]_{\mathrm{o}}\right) /\left(\mathrm{P}_{\mathrm{K}}[\mathrm{K}]_{\mathrm{i}}+\mathrm{P}_{\mathrm{Na}}[\mathrm{Na}]_{\mathrm{i}}\right)\right\}\right.$. Where $\mathrm{E}_{\text {rev }}$ is the reversal potential of $\mathrm{CRH}$-induced current, $\mathrm{P}_{\mathrm{K}}$ and $\mathrm{P}_{\mathrm{Na}}$ are permeability for $\mathrm{K}^{+}$and $\mathrm{Na}^{+}$, respectively, and $[\mathrm{K}]_{\mathrm{o}}$ and $[\mathrm{Na}]_{\mathrm{o}}$ stand for extracllular concentration of $\mathrm{K}^{+}$and $\mathrm{Na}^{+}$, respectively. $[\mathrm{K}]_{\mathrm{i}}$ and $[\mathrm{Na}]_{\mathrm{i}}$ stand for intracellular concentration of $\mathrm{K}^{+}$and $\mathrm{Na}^{+}$, respectively. $\mathrm{R}$ is the gas constant, $\mathrm{T}$ the absolute temperature, and $\mathrm{F}$ the Faraday's constant. RT/F is nearly 25.69 at $25^{\circ} \mathrm{C}$. In this equation, $[\mathrm{K}]_{\mathrm{o}}$ and $[\mathrm{Na}]_{\mathrm{i}}$ were 0 $\mathrm{mM},[\mathrm{Na}]_{\mathrm{o}}$ was $143 \mathrm{mM}$, and $[\mathrm{K}]_{\mathrm{i}}$ was $144 \mathrm{mM}$. Permeability ratio of $\mathrm{CRH}$-induced current to $\mathrm{K}^{+}$and $\mathrm{Na}^{+}\left(\mathrm{P}_{\mathrm{K}} / \mathrm{P}_{\mathrm{Na}}\right)$ was cal- 
culated to be $\sim 1.4$. However, because the I-V curve of the $\mathrm{CRH}$-induced current showed slight inward rectification, the reversal potential estimated by extrapolating the I-V relations between -48 and $-68 \mathrm{mV}$ may be slightly more hyperpolarized to the true reversal potential. Therefore, $\mathrm{P}_{\mathrm{K}} / \mathrm{P}_{\mathrm{Na}}$ may be a little smaller than calculated, meaning that the $\mathrm{CRH}$-induced current may be a little more permeable to $\mathrm{Na}^{+}$than calculated.

Extracellular $\mathrm{Na}^{+}$-dependency of the $\mathrm{CRH}$-induced $\left[\mathrm{Ca}^{2+}\right]_{i}$ increase. Application of $10 \mathrm{nM} \mathrm{CRH}$ increased $\left[\mathrm{Ca}^{2+}\right]_{\mathrm{i}}$ of these cells (Fig. $4 A$ ) in the standard extracellular solution.

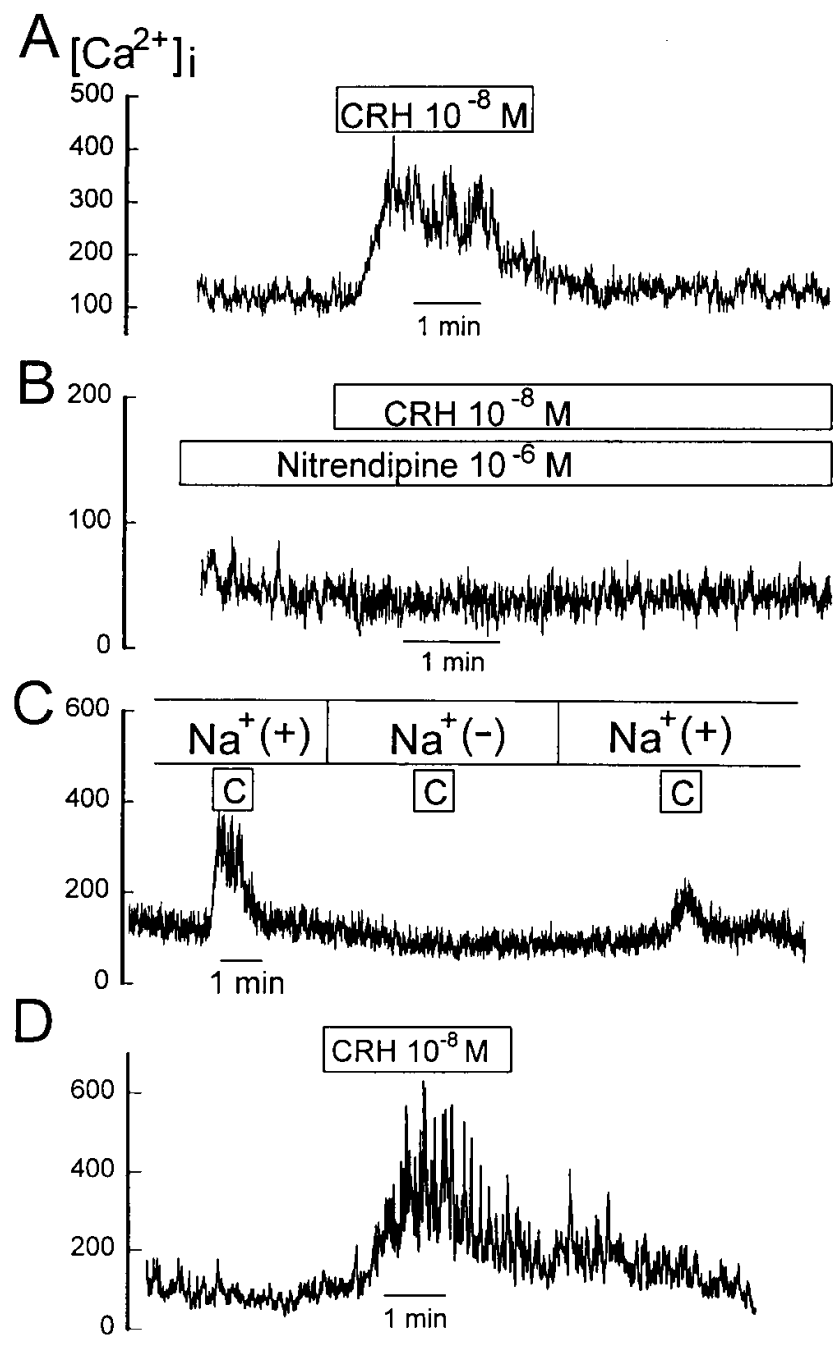

Figure 4. $\mathrm{CRH}$-induced $\left[\mathrm{Ca}^{2+}\right]_{\mathrm{i}}$ increase in ACTH-secreting adenoma cells. (A) Application of $10 \mathrm{nM} \mathrm{CRH}$ increased $\left[\mathrm{Ca}^{2+}\right]_{\mathrm{i}}$ in the standard extracellular solution. $(B) \mathrm{CRH}$-induced $\left[\mathrm{Ca}^{2+}\right]_{\mathrm{i}}$ increase was not observed in the standard extracellular solution containing 1 $\mu \mathrm{M}$ nitrendipine $(C)$ extracellular $\mathrm{Na}^{+}$dependency of $\mathrm{CRH}$-induced $\left[\mathrm{Ca}^{2+}\right]_{\mathrm{i}}$ increase. Application of CRH $(10 \mathrm{nM})$ increased $\left[\mathrm{Ca}^{2+}\right]_{\mathrm{i}}$ in a cell in the standard extracellular solution. After changing the extracellular solution with $\mathrm{Na}^{+}$-free extracellular solution, $\mathrm{CRH}(10 \mathrm{nM})$ was again applied. $\mathrm{CRH}$ did not increase $\left[\mathrm{Ca}^{2+}\right]_{\mathrm{i}}$ in $\mathrm{Na}^{+}$-free solution. However, when the extracellular solution was changed to the standard extracellular solution again, the increase in $\left[\mathrm{Ca}^{2+}\right]_{\mathrm{i}}$ by $\mathrm{CRH}$ $(10 \mathrm{nM})$ was observed. $\mathrm{Na}^{+}(+)$indicates that the extracellular solution is the standard extracellular solution and $\mathrm{Na}^{+}(-)$indicates that the extracellular solution was $\mathrm{Na}^{+}$-free. $(D) \mathrm{CRH}$ increased $\left[\mathrm{Ca}^{2+}\right]_{\mathrm{i}}$ in the standard extracellular solution containing $5 \mu \mathrm{M}$ TTX.
This increase was a reversible phenomenon. Fig. $4 B$ shows the effect of nitrendipine on $\mathrm{CRH}$-induced $\left[\mathrm{Ca}^{2+}\right]_{\mathrm{i}}$ change. Application of nitrendipine $(1 \mu \mathrm{M})$ decreased $\left[\mathrm{Ca}^{2+}\right]_{\mathrm{i}}$ by itself and further application of CRH $(10 \mathrm{nM})$ together with nitrendipine $(1 \mu \mathrm{M})$ did not increase $\left[\mathrm{Ca}^{2+}\right]_{\mathrm{i}}$, indicating that $\mathrm{Ca}^{2+}$ influx through L-type voltage-gated $\mathrm{Ca}^{2+}$ channel is responsible for the $\left[\mathrm{Ca}^{2+}\right]_{\mathrm{i}}$ increase. Similar results were obtained in six cells in adenoma 1 , and four cells in adenoma 2.

The extracellular $\mathrm{Na}^{+}$-dependency of the CRH-induced $\left[\mathrm{Ca}^{2+}\right]_{\mathrm{i}}$ increase was examined. Fig. $4 \mathrm{C}$ shows the $\left[\mathrm{Ca}^{2+}\right]_{\mathrm{i}}$ of another adenoma cell. Application of $\mathrm{CRH}$ increased $\left[\mathrm{Ca}^{2+}\right]_{i}$ of the cell in the standard extracellular solution. After changing the extracellular solution to $\mathrm{Na}^{+}$-free solution, $\mathrm{CRH}(10 \mathrm{nM})$ was applied in the $\mathrm{Na}^{+}$-free extracellular solution. $\mathrm{CRH}$ did not increase $\left[\mathrm{Ca}^{2+}\right]_{\mathrm{i}}$ in this solution. The lack of $\mathrm{CRH}$ response in $\mathrm{Na}^{+}$-free solution was not due to the $\mathrm{CRH}$ receptor desensitization because $\mathrm{CRH}$-induced $\left[\mathrm{Ca}^{2+}\right]_{\mathrm{i}}$ increase was observed again when the extracellular solution was returned to the standard extracellular solution. These data indicate that the CRHinduced $\left[\mathrm{Ca}^{2+}\right]_{i}$ increase was extracellular $\mathrm{Na}^{+}$dependent. Similar results were obtained in four other cells. To see that the extracellular $\mathrm{Na}^{+}$-dependency of the $\mathrm{CRH}$-induced $\left[\mathrm{Ca}^{2+}\right]_{i}$ increase was not related to $\mathrm{Na}^{+}$-action potentials, the standard extracellular solution containing $5 \mu \mathrm{M}$ tetrodotoxin (TTX) was used. In this condition, $\mathrm{CRH}$ increased $\left[\mathrm{Ca}^{2+}\right]_{i}$ of these cells (Fig. $4 \mathrm{D}$ ), indicating that abolishment of TTX-sensitive $\mathrm{Na}^{+}$ action potentials is not the cause of the abolishment of CRHinduced $\left[\mathrm{Ca}^{2+}\right]_{\mathrm{i}}$ increase in the $\mathrm{Na}^{+}$-free extracellular solution.

PKA-mediated activation of $\mathrm{CRH}$-induced cation current. Fig. $5 \mathrm{~A}$ shows the membrane current before and after the application of $10 \mu \mathrm{M}$ forskolin under voltage clamp. A ramp test potential from -120 to $-50 \mathrm{mV}$ in $800 \mathrm{~ms}$ was applied to ob-

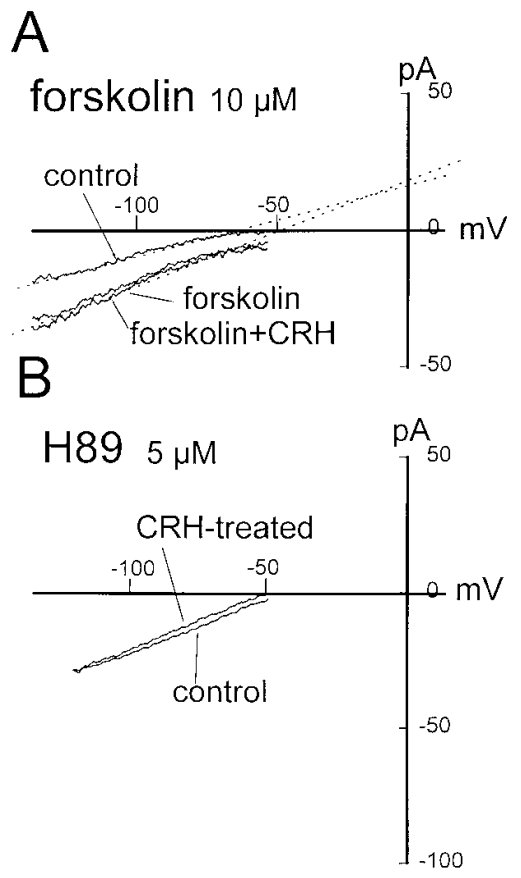

Figure 5. Relationship between $\mathrm{CRH}$-induced current and cAMP. $(A)$ Effect of forskolin on the membrane current Forskolin was applied to cells with or without $10 \mathrm{nM}$ CRH. Broken lines were drawn by eye. Control indicates current record before the application of forskolin, forskolin indicates current record after the application of forskolin, and forskolin $+\mathrm{CRH}$ indicates current record after the combined application of forskolin and CRH. (B) Effect of H89 on the CRH-induced current. Application of CRH (10 nM) did not change the membrane current in a cell pre-

treated with $\mathrm{H} 89(5 \mu \mathrm{M})$ for $30 \mathrm{~min}$. Extracellular solution and ramp pulse protocol were the same as in Fig. $3 \mathrm{~A}$. Control indicates current record before the application of $\mathrm{CRH}$, and $\mathrm{CRH}$-treated indicates current record after the application of CRH. 
tain the I-V relationship from the holding potential of -48 $\mathrm{mV}$. Forskolin $(10 \mu \mathrm{M})$ induced an inward current whose reversal potential was between the equilibrium potential of $\mathrm{Na}^{+}$ and $\mathrm{K}^{+}$, suggesting that the induced current was a nonselective cation current. After maximal response was achieved by forskolin, CRH $(10 \mathrm{nM})$ was applied together with forskolin, which did not induce additional change in the membrane current $(n=5)$. These data indicate that forskolin induced a cation current and occluded the effect of CRH on the membrane current. These suggest that $\mathrm{CRH}$ activates the cation current through the activation of an adenylyl cyclase. When a cell-permeable cAMP analogue, 8Br-cAMP (100 nM), was applied to the cell, similar cation current was induced and the effect of $\mathrm{CRH}$ on membrane current was occluded by this compound, as was the case for forskolin (data not shown).

To investigate whether PKA is involved in the $\mathrm{CRH}$-induced activation of the cation current, a PKA-inhibitor H89 (14) was used. Fig. $5 B$ shows the membrane currents before and after the application of CRH $(10 \mathrm{nM})$ in a cell pretreated with $5 \mu \mathrm{M}$ H89 for $30 \mathrm{~min}$. CRH did not induce the cation current in H89treated cells $(n=7)$. Because $\mathrm{H} 89$ was not a specific inhibitor for PKA, a specific PKA-inhibitor PKI(5-24) was injected into the cell by microinjection technique. As a control peptide, a specific PKC-inhibitor PKC(19-36) was used. Fig. 6 A shows the effect of $\mathrm{CRH}$ on the membrane current of a cell microinjected with PKI(5-24). CRH did not induce any change on the membrane current. Microinjection of PKC(19-36) did not
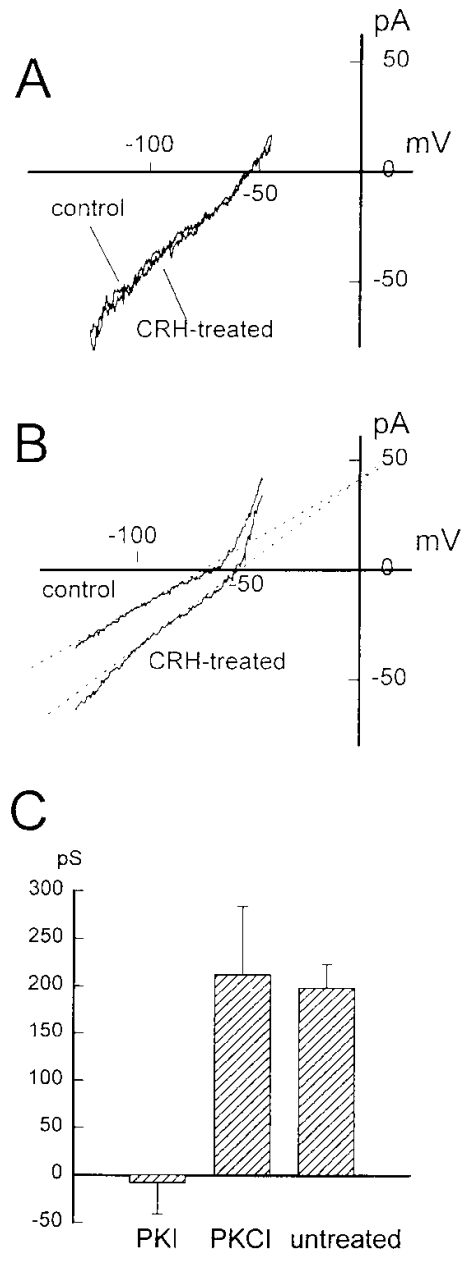

Figure 6. Effect of microinjected PKI(5-24) on the (A) Cells had been in jected with PKI(5-24) by microinjection and was applied with CRH (10 nM). Application of CRH did rent. $(B)$ Cell had been injected with PKC(19-36) by microinjection and was applied with CRH (10 nM) $\mathrm{CRH}$ induced a cation current. Control indicates curplication of $\mathrm{CRH}$, and RH-treated indicates current record after the application of CRH. (C) The ductance in cells injected PKI(5-24), and in untreated cells. PKCI, the jected obtained from cells PKI, the data obtained from cells injected with PKI(5-24); untreated, data obtained from untreated cells. The bar indicates 1 SD. $* P<0.01$; data were analyzed by ANOVA. with PKC(19-36) or abolish the $\mathrm{CRH}$-induced activation of the cation current (Fig. $6 \mathrm{~B})$. Fig. $6 \mathrm{C}$ summarizes the results of these experiments. The $\mathrm{CRH}$ response in $\mathrm{PKI}(5-24)$-injected cells was profoundly attenuated compared with the response in PKC(19-36)-injected cells, which was not significantly different from that in untreated cells.

Independency of CRH-induced cation current on $\left[\mathrm{Ca}^{2+}\right]_{i}$. There are a group of nonselective cation currents that are activated by the increase in $\left[\mathrm{Ca}^{2+}\right]_{\mathrm{i}}$ in various kinds of cells (15-17). Because $\mathrm{CRH}$ increased $\left[\mathrm{Ca}^{2+}\right]_{i}$ of these ACTH-secreting adenoma cells, it is possible that the $\mathrm{CRH}$-induced cation current is one of the $\mathrm{Ca}^{2+}$-activated cation currents. To investigate this, we loaded the cell with cell-permeable $\mathrm{Ca}^{2+}$ chelator, BAPTA/AM, to clamp the $\left[\mathrm{Ca}^{2+}\right]_{\mathrm{i}}$ lower than $100 \mathrm{~nm}$, at which $\mathrm{Ca}^{2+}$-activated cation currents are activated (18). Fig. $7 \mathrm{~A}$ shows the time course of the $\left[\mathrm{Ca}^{2+}\right]_{\mathrm{i}}$ of a cell incubated for $100 \mathrm{~min}$ in the standard extracellular solution containing BAPTA/AM $(10 \mu \mathrm{M})$ and $0.1 \%$ BSA. The initial $\left[\mathrm{Ca}^{2+}\right]_{\mathrm{i}}$ was $\sim 250 \mathrm{nM}$ and decreased gradually during the incubation.

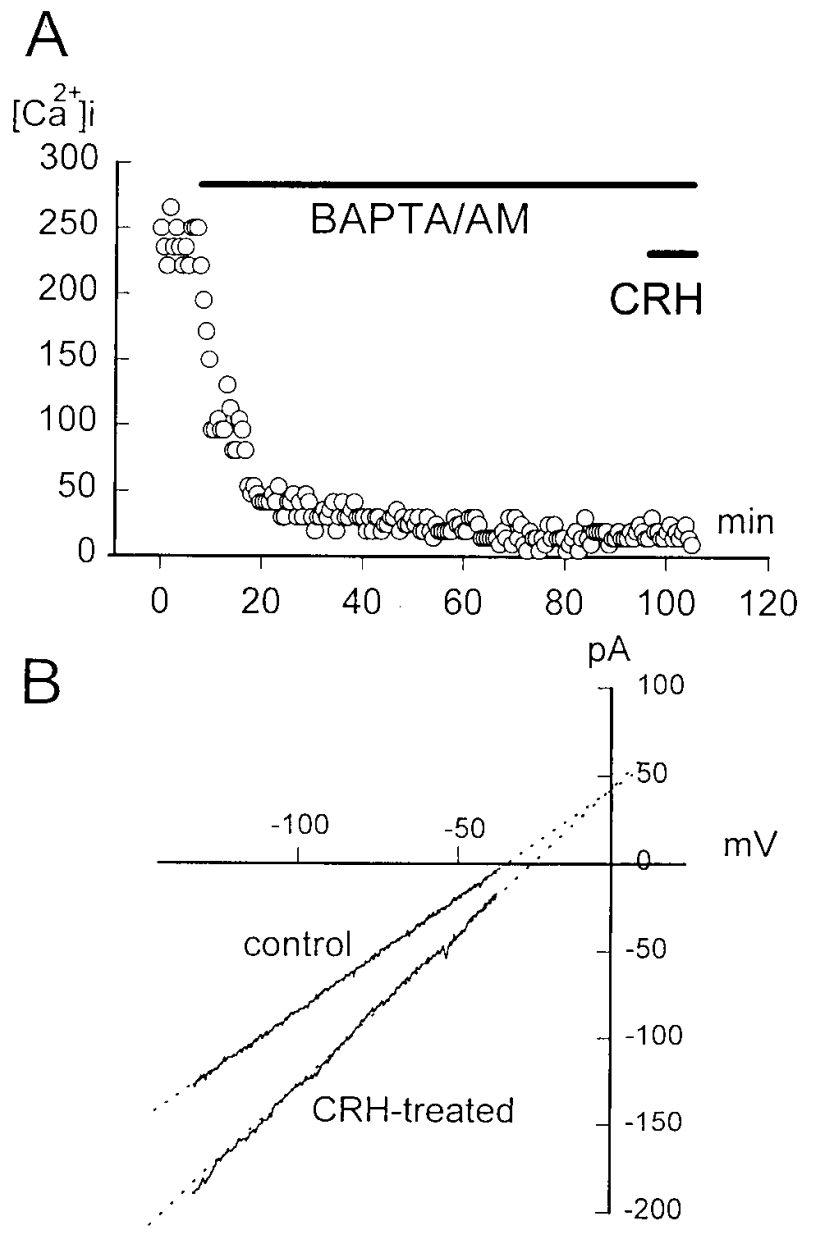

Figure 7. (A) Time course of $\left[\mathrm{Ca}^{2+}\right]_{\mathrm{i}}$ of a cell during incubation in the standard extracellular solution containing BAPTA/AM $(10 \mu \mathrm{M})$ and $0.1 \%$ BSA over $100 \mathrm{~min}$. BAPTA/AM indicates incubation with BAPTA/AM. CRH indicates application of CRH (10 nM). (B) Membrane currents evoked by a ramp test potential before and after the application of CRH (10 nM) of the BAPTA/AM-treated cell (for 100 $\min$ ) in $\mathrm{Na}^{+}$-free extracellular solution. Control, current record before the application of $\mathrm{CRH}$; $\mathrm{CRH}$-treated, current record after the

application of $\mathrm{CRH}$. 
Finally, it reached $\sim 30 \mathrm{nM}$ at $100 \mathrm{~min}$. Application of CRH $(10 \mathrm{nM})$ did not increase $\left[\mathrm{Ca}^{2+}\right]_{\mathrm{i}}$ at this point. When the results from five experiments were summarized, the value of $\left[\mathrm{Ca}^{2+}\right]_{\mathrm{i}}$ after $100 \mathrm{~min}$ BAPTA/AM treatment was $25 \pm 10 \mathrm{nM}$ and ranged between 15 and $45 \mathrm{nM}$. It did not increase after the application of CRH $(10 \mathrm{nM})$ and remained around $27 \pm 17 \mathrm{nM}$, ranging between 20 and $50 \mathrm{nM}$. Therefore, treating the cell with BAPTA/AM for 100 min was enough to clamp $\left[\mathrm{Ca}^{2+}\right]_{\mathrm{i}}$ lower than $50 \mathrm{nM}$ even when CRH is to be applied. We investigated the effect of CRH $(10 \mathrm{nM})$ on the membrane current after treating the cell with BAPTA/AM as mentioned above. In addition to the treatment by BAPTA/AM, we used $\mathrm{Ca}^{2+}$-free extracellular solution to avoid the local $\left[\mathrm{Ca}^{2+}\right]_{i}$ increase beneath the plasma membrane due to the $\mathrm{Ca}^{2+}$ influx through the voltage-gated $\mathrm{Ca}^{2+}$ channels. Fig. $7 \mathrm{~B}$ shows the membrane current evoked by a ramp test potential before and after the application of CRH $(10 \mathrm{nM})$ on a BAPTA/AM-treated cell. $\mathrm{CRH}$ induced a cation current in this cell. Application of CRH induced a cation current in the BAPTA/AM-treated $(100 \mathrm{~min})$ cells in $\mathrm{Ca}^{2+}$-free extracellular solution in six out of six cells, including this cell. These data suggest that the cation current induced by $\mathrm{CRH}$ is not a member of the $\mathrm{Ca}^{2+}$-activated cation currents.

Hormone release study. To estimate the role of $\mathrm{CRH}$-induced cation current in CRH-induced hormone secretion, human ACTH secretion from adenoma cells was measured. Adenoma cells were incubated in $\mathrm{Na}^{+}$-free extracellular solution, and the effect of CRH application on the ACTH secretion was examined. Fig. 8 shows the effects of CRH on ACTH secretion from primary cultured cells of adenoma 1. CRH increased ACTH secretion in $\mathrm{Na}^{+}$-containing extracellular solution with a concentration dependency. CRH $(100 \mathrm{nM})$ increased the secretion to the level of $300 \pm 45 \%($ mean $\pm \mathrm{SD}, n=4)$ of the control. The CRH-induced increase of ACTH secretion was abolished in $\mathrm{Na}^{+}$-free $\left(\mathrm{TMA}^{+}\right)$extracellular solution, indicating that CRH-induced increase of ACTH secretion was dependent on extracellular $\mathrm{Na}^{+}$. These data suggest that CRHinduced activation of $\mathrm{Na}^{+}$-permeable (nonselective) cation

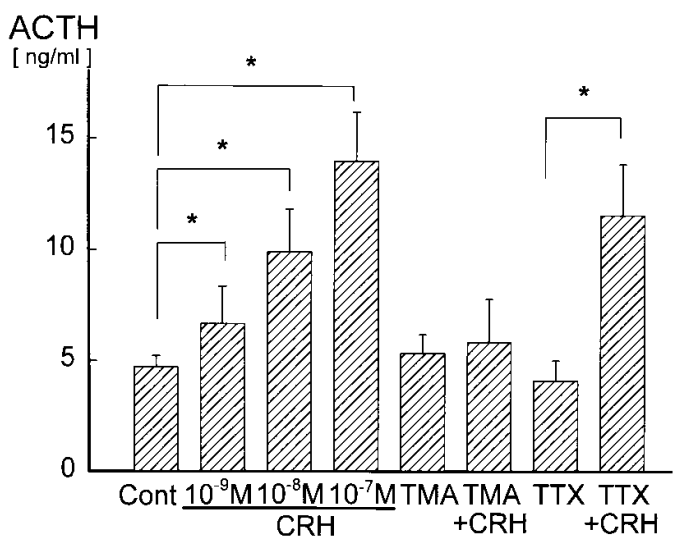

Figure 8. CRH-induced ACTH secretion. Cont, control extracellular medium; $\mathrm{TMA}^{+}, \mathrm{Na}^{+}$-free extracellular medium; $\mathrm{TMA}^{+}+\mathrm{CRH}$, $\mathrm{Na}^{+}$-free extracellular medium containing $10 \mathrm{nM}$ CRH; TTX, control extracellular medium containing $5 \mu \mathrm{M}$ TTX; TTX $+\mathrm{CRH}$, control extracellular medium containing $5 \mu \mathrm{M}$ TTX and $10 \mathrm{nM}$ CRH. Data are shown as mean \pm SD of data from four wells. Bar indicates 1 SD. $* P<0.05$. The data were analyzed by ANOVA and found to be significantly different $(P<0.01)$ and difference between each pair was analyzed by post test.

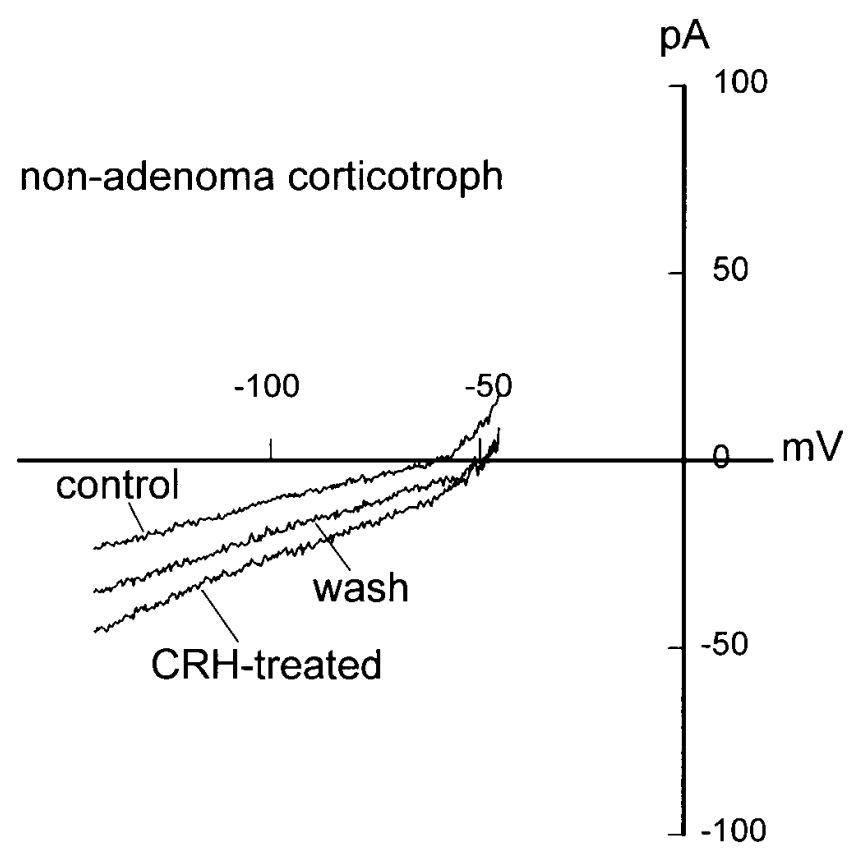

Figure 9. Effect of CRH on a nonadenoma cell. Resting potential was $-58 \mathrm{mV}$. Application of $\mathrm{CRH}(10 \mathrm{nM})$ induced a current with reversal potential $\sim 0 \mathrm{mV}$. Holding potential and ramp pulse protocols were the same as those in Fig. $3 \mathrm{~A}$. Control, current record before the application of $\mathrm{CRH}$; CRH-treated, current record after the application of $\mathrm{CRH}$; and wash, current record after washing out $\mathrm{CRH}$ from the extracellular solution.

channel play an important role in the mechanism of CRHinduced ACTH secretion.

Activation of a nonselective cation current in nonadenoma corticotroph by $C R H$. To investigate whether the activation of the nonselective cation current was specific in adenoma cells or a common feature in corticotrophs, nonadenoma anterior pituitary cells were used. These cells were primary cultured from a small fragment of the nonadenoma anterior pituitary tissue that had to be resected to make approach to the adenoma during the transsphenoidal procedure (see Cell preparation, Methods). It was difficult to distinguish between corticotrophs and other cell types morphologically. Therefore, we randomly challenged the cells with CRH $(10 \mathrm{nM})$ under voltage clamp. In 4 out of 28 cells, application of CRH activated a cation current. Fig. 9 shows representative current records evoked by a ramp test potential before and after the application of CRH. The reversal potential was close to $0 \mathrm{mV}$, suggesting that the current was a nonselective cation current. All the four cells were stained positive for human ACTH and only 1 of the 24 cells that did not respond to CRH were stained positive for human ACTH. These indicate that $\mathrm{CRH}$ activates a nonselective cation current in at least some of the nonadenoma corticotrophs.

\section{Discussion}

$\mathrm{CRH}$ is the major regulatory peptide of the neuroendocrine response to stress (2). It is secreted from hypothalamic $\mathrm{CRH}$ neurons and excites ACTH-secreting cells in the anterior pituitary. The mechanism of this excitation was investigated by using human ACTH-secreting adenoma cells in this study. These 
adenoma cells were excited by the application of CRH and secreted ACTH in vitro. The excitation was caused by $\mathrm{CRH}-$ induced depolarization through the activation of a nonselective cation current. The I-V curve of this cation current showed slight inward rectification. This channel was permeable to other cations such as $\mathrm{Li}^{+}$and $\mathrm{NH}_{4}{ }^{+}$, but was not permeable to $\mathrm{TMA}^{+}$. The inward current was abolished when the extracellular solution was $\mathrm{Na}^{+}$-free $\left(\mathrm{TMA}^{+}\right.$-substituted) and the intracellular solution contained high $\mathrm{K}^{+}$. Because the cation current was permeable to both $\mathrm{Na}^{+}$and $\mathrm{K}^{+}$, the activation of the current in $\mathrm{Na}^{+}$-free (TMA ${ }^{+}$-substituted) extracellular solution with high $\mathrm{K}^{+}$intracellular solution was expected to induce an outward current. Interestingly, the expected outward current carried by $\mathrm{K}^{+}$was also not observed. This absence of the expected outward current may be explained by the inward rectification of the $\mathrm{CRH}$-induced nonselective cation current. The activation of a nonselective cation current by $\mathrm{CRH}$ has not been reported in vertebrate cells, including human corticotrophs.

In several cells, including cardiac and pancreas acinar cells, nonselective cation channels are activated by the increase in $\left[\mathrm{Ca}^{2+}\right]_{\mathrm{i}}(15-17)$. Because CRH increased $\left[\mathrm{Ca}^{2+}\right]_{\mathrm{i}}$ in these adenoma cells, we speculated that $\mathrm{CRH}$-induced activation of the cation channel was mediated by $\mathrm{CRH}$-induced $\left[\mathrm{Ca}^{2+}\right]_{\mathrm{i}}$ increase. However, CRH-induced activation of the nonselective cation current was observed even when $\left[\mathrm{Ca}^{2+}\right]_{\mathrm{i}}$ was chelated lower than $50 \mathrm{nM}$ by incubation with BAPTA/AM in $\mathrm{Ca}^{2+}$-free extracellular solution. Most of the $\mathrm{Ca}^{2+}$-activated cation currents are activated when the $\left[\mathrm{Ca}^{2+}\right]_{\mathrm{i}}$ was higher than $100 \mathrm{nM}$. Therefore, these data suggest that $\mathrm{CRH}$-activated nonselective cation current is not a member of the $\mathrm{Ca}^{2+}$-activated cation currents.

The activation of this current was mimicked by forskolin and $8 \mathrm{Br}$-cAMP. Microinjection of PKA inhibitor peptide into the cell abolished the activation of the $\mathrm{CRH}$-induced current. These data indicate that the mechanism of CRH-induced activation of the nonselective cation current was mediated by PKA. Modulation of ionic channels through PKA-mediated phosphorylation is reported for voltage-gated $\mathrm{Ca}^{2+}$ and $\mathrm{K}^{+}$channels in several types of cells $(19,20)$. In human growth hormonesecreting adenoma cells, GHRH excited the cells by activating a nonselective cation current through a PKA-mediated mechanism (21). The activation of the nonselective cation current may be a common mechanism of excitation in human anterior pituitary cells for agonists that stimulate cAMP production.

The excitation of the corticotrophs by CRH has been investigated in rat pituitary (22). There were obvious differences between rat corticotrophs and these human ACTH-secreting adenoma cells in the mechanism of $\mathrm{CRH}$-induced excitation. (a) The excitation in rat corticotrophs are suggested to be due to the inhibition of $\mathrm{K}^{+}$conductance, and not by an increase in cation conductance. (b) The excitation by CRH was not completely blocked by $\mathrm{H} 89$ in rat corticotrophs, whereas it was almost abolished by H89 or PKI(5-24) in human ACTHsecreting adenoma cells. The differences in the mechanism of $\mathrm{CRH}$-induced excitation in the ACTH-secreting cell may be due to the difference of species or the difference between normal cells and adenoma cells. The former may be the case because CRH also induced a cation current in nonadenoma human corticotrophs. The combination of the activation of a nonselective cation current and inhibition of $\mathrm{K}^{+}$conductance is a very commonly observed response to neurotransmitters and hormones and typically the two components differ in mag- nitude among cells (23-25). It may simply be that the balance between these two pathways is different between rat and human corticotrophs.

$\mathrm{CRH}$-induced depolarization was previously reported in human ACTH-secreting adenoma cells by Mollard et al. (26). In their report, application of $\mathrm{CRH}$ depolarized the membrane with an increase in input resistance. They speculated that the depolarization is due to the inhibition of $\mathrm{K}^{+}$conductance. In the adenoma cells in this article, the excitation was due to the activation of a nonselective cation current. The difference in the mechanism of excitation is very interesting because it suggests an unknown variety of mechanisms of tumorigenesis in human ACTH-secreting adenomas. However, the difference may be due to the difference of experimental technique. In the report of Mollard et al. (26), they employed an intracellular recording technique. In this report, we used the perforated whole-cell clamp. Further studies are needed to understand the relation between the $\mathrm{CRH}$-induced inhibition of membrane conductance in their study and $\mathrm{CRH}$-induced nonselective cation conductance revealed in our study.

In these ACTH-secreting cells, CRH-induced $\left[\mathrm{Ca}^{2+}\right]_{\mathrm{i}}$ increase was dependent on $\mathrm{Ca}^{2+}$ influx through voltage-gated $\mathrm{Ca}^{2+}$ channels. CRH-induced $\left[\mathrm{Ca}^{2+}\right]_{\mathrm{i}}$ increase was dependent on extracellular $\mathrm{Na}^{+}$and was not dependent on TTX-sensitive $\mathrm{Na}^{+}$channel activities. These indicate that the $\mathrm{Na}^{+}$-dependent nonselective cation current is important in $\mathrm{CRH}$-induced $\left[\mathrm{Ca}^{2+}\right]_{i}$ increase. The $\mathrm{CRH}$-induced depolarization together with increased action potential frequency activates voltagegated $\mathrm{Ca}^{2+}$ channels. The $\mathrm{Ca}^{2+}$ influx through voltage-gated $\mathrm{Ca}^{2+}$ channels increases $\left[\mathrm{Ca}^{2+}\right]_{i}$ of these cells. As $\left[\mathrm{Ca}^{2+}\right]_{\mathrm{i}}$ is closely related to $\mathrm{ACTH}$ secretion rate in $\mathrm{ACTH}$-secreting cells $(27,28)$, the $\mathrm{CRH}$-induced $\left[\mathrm{Ca}^{2+}\right]_{\mathrm{i}}$ increase due to membrane depolarization stimulates ACTH secretion. Therefore, $\mathrm{CRH}$-induced depolarization may play a major role in $\mathrm{CRH}$ induced ACTH secretion. This speculation is supported by the following observations: (a) both the CRH-induced cation current (which causes depolarization) and $\mathrm{CRH}$-induced ACTH secretion were abolished in $\mathrm{Na}^{+}$-free extracellular solution; (b) $\mathrm{CRH}$-induced $\left[\mathrm{Ca}^{2+}\right]_{\mathrm{i}}$ increase was abolished in $\mathrm{Na}^{+}$-free extracellular solution; $(c)$ both the $\mathrm{CRH}$-induced ACTH secretion and $\mathrm{CRH}$-induced $\left[\mathrm{Ca}^{2+}\right]_{\mathrm{i}}$ increase were not abolished by TTX. These indicate that extracellular $\mathrm{Na}^{+}$-dependent depolarization is crucially important in $\mathrm{CRH}$-induced ACTH secretion. However, the significance of the $\mathrm{CRH}$-induced nonselective cation current in $\mathrm{CRH}$-induced $\mathrm{ACTH}$ secretion was not examined in nonadenoma corticotrophs because the amount of the nonadenoma tissue available was limited. This question needs further study to solve.

\section{Acknowledgments}

This study was performed in collaboration with Dr. Naohide Yamashita (University of Tokyo School of Medicine). We thank Dr. Tsukasa Takei for technical support.

This work was supported by grants from the Ministry of Education (Japan).

\section{References}

1. Vale, W., J. Spiess, C. Rivier, and J. Rivier. 1981. Characterization of a 41-residue ovine hypothalamic peptide that stimulates secretion of corticotro- 
pin and $\beta$-endorphin. Science (Wash. DC). 213:1394-1397.

2. Owens, M.J., and C.B. Nemeroff. 1991. Physiology and pharmacology of corticotropin-releasing factor. Pharmacol. Rev. 43:425-473.

3. Labrie, F., R. Veilleux, and G. Lefevre. 1982. Corticotropin-releasing factor stimulates accumulation of adenosine $3^{\prime}, 5^{\prime}$-monophosphate in rat pituitary corticotrophs. Science (Wash. DC) 216:1007-1008

4. Giguere, V., F.R. Labrie, D.H. Coy, J. Sueriras-Diaz, and A.V. Schally. 1982. Stimulation of cyclic AMP accumulation and corticotropin release by synthetic ovine corticotropin-releasing factor in rat anterior pituitary cells: site of glucocorticoid action. Proc. Natl. Acad. Sci. USA. 79:3466-3469.

5. Luini, A., D. Lewis, S. Guild, D. Corda, and J. Axelrod. 1985. Hormone secretagogues increase cytosolic calcium by increasing cAMP in corticotropinsecreting cells. Proc. Natl. Acad. Sci. USA. 82:8034-8038.

6. Abou-Samra, A.B., K.J. Catt, and G. Aguilera. 1987. Calcium-dependent control of corticotropin release in rat anterior pituitary cell cultures. Endocrinology. 121:965-971.

7. Guerineau, N., J.B. Corcuff, A. Tabarin, and P. Mollard. 1991. Spontaneous and corticotropin-releasing factor-induced cytosolic calcium transients in corticotrophs. Endocrinology. 129:409-420.

8. Horn, R., and A. Marty. 1988. Muscarinic activation of ionic currents measured by a new whole-cell recording method. J. Gen. Physiol. 92:145-159.

9. Yamashita, N., and S. Hagiwara. 1990. Membrane depolarization and intracellular $\mathrm{Ca}^{2+}$ increase caused by high external $\mathrm{Ca}^{2+}$ in a rat calcitonin-secreting cell line. J. Physiol. (Lond.). 431:243-267.

10. Takano, K., P.R. Stanfield, S. Nakajima, and Y. Nakajima. 1995. Protein kinase $\mathrm{C}$-mediated inhibition of inwardly rectifying $\mathrm{K}^{+}$channel by substance $\mathrm{P}$ in nucleus basalis neuron. Neuron. 14:999-1008.

11. Tsien, R.Y. 1980. New calcium indicators and buffers with high selectivity against magnesium and proteins: design, synthesis and properties of prototype structures. Biochemistry. 19:2396-2404.

12. Goldman, D.E. 1943. Potential, impedance, and rectification in membrane. J. Gen. Physiol. 27:37-60.

13. Hodgkin, A.L., and B. Katz. 1949. The effect of sodium ions on the electrical activity of the giant axon of the squid. J. Physiol. (Lond.). 108:37-77.

14. Chijiwa, T., A. Mishima, M. Hagiwara, M. Sano, K. Hayashi, T. Inoue, K. Naito, T. Toshioka, and H. Hidaka. 1990. Inhibition of forskolin-induced neurite outgrowth and protein phosphorylation by a newly synthesized selective inhibitor of cyclic AMP-dependent protein kinase, $N$-[2-( $p$-bromocynnamylamino)ethyl]-5-isoquinoleinsulfonamide (H89), of PC12D pheochromocytoma cells. J. Biol. Chem. 265:5267-5272.
15. Colquhoun, D., E. Neher, and H. Reuter. 1981. Inward current channels activated by intracellular $\mathrm{Ca}^{2+}$ in cultured cardiac cells. Nature (Lond.). 294: $752-754$.

16. Yellen, G. 1981. Single $\mathrm{Ca}^{2+}$-activated non-selective cation channels in neuroblastoma. Nature (Lond.). 296:357-359.

17. Maruyama, Y., and H. Peterson. 1982. Single-channel currents in isolated patches of plasma membrane from basal surface of pancreatic acini. $\mathrm{Na}$ ture (Lond.). 299:159-161.

18. Siemen, D., and J. Hescheler. 1993. Nonselective cation channels. Birkhäuser Verlag. (XLS: 66).

19. Hartzell, H.C., P.F. Mery, R. Fischmeister, and G. Zabo. 1990. Sympathetic regulation of cardiac calcium current is due exclusively to cAMP-dependent phosphorylation. Nature (Lond.). 351:573-576.

20. Reinhart, P.H., S. Chung, B.L. Martin, D.L. Brautigan, and I.B. Levitan. 1991. Modulation of calcium-activated potassium channels from rat brain by protein kinase A and phosphatase 2A. J. Neurosci. 11:1627-1635.

21. Takano, K., T. Takei, A. Teramoto, and N. Yamashita. 1996. Growth hormone-releasing hormone activates a cation current in human growth hormone-secreting adenoma cells. Am. J. Physiol. 270:1050-1057.

22. Kuryshev, Y.A., G.V. Childs, and A.K. Ritchie. 1995. Corticotropinreleasing hormone stimulation of $\mathrm{Ca}^{2+}$ entry in corticotropes is partially dependent on protein kinase A. Endocrinology. 136:3925-3935.

23. Kuba, K., and K. Koketsu. 1978. Synaptic events in sympathetic ganglia. Prog. Neurobiol (Oxf.). 11:77-169.

24. Shen, K.-Z., and R.A. North. 1992. Muscarine increases cation conductance and decreases potassium conductance in rat locus coeruleus neurones. $J$. Physiol. (Lond.). 455:471-485.

25. Shen, K.-Z., and R.A. North. 1992. Substance P opens cation channels and closes potassium channels in rat locus coeruleus neurons. Neuroscience. 50: 345-353.

26. Mollard, P., P. Vacher, J. Guerin, M.A. Rogawski, and B. Dufy. 1987. Electrical properties of cultured human adrenocorticotropin-secreting adenoma cells: effects of high $\mathrm{K}^{+}$, corticotropin-releasing factor, and angiotensin 2 . Endocrinology. 121:395-405.

27. Ozawa, S., and O. Sand. 1986. Electrophysiology of excitable endocrine cells. Physiol. Rev. 66:887-951.

28. Won, J.G.S., and D.N. Orth. 1990. Roles of intracellular and extracellular calcium in the kinetic profile of adrenocorticotropin secretion by perifused rat anterior pituitary cells. 1. Corticotropin-releasing factor stimulation. Endocrinology. 126:849-857. 